\title{
The effect of diet composition and length of storing eggs on changes in the fatty acid profile of egg yolk
}

\author{
A. Boruta ${ }^{1}$ and J. Niemiec \\ Warsaw Agricultural University, \\ Department of Poultry Breeding \\ Ciszewskiego 8, 02-786 Warszawa, Poland
}

\begin{abstract}
The objective of this study was to determine the effect of diet composition and the length of storing eggs on the fatty acid (FA) composition of egg yolks. The study was conducted on eggs from Messa 45 hens. The experimental groups were fed diets D1 and D2 containing rape, linseed and evening primrose seeds. The D2 diet contained vitamin E $200 \mathrm{mg} / \mathrm{kg}$, added as an antioxidant to the feed. The FA content and TBA level in fresh yolks and in yolks from eggs that had been stored for 3 or 6 months at $-25^{\circ} \mathrm{C}$ were determined. It was found that both the diet and duration of storage significantly affected the MUFA and PUFA contents in total fatty acids. The observed changes in the PUFA content indicate that vitamin E slowed down the process of oxidation of egg yolk fat. During storage, the extinction of TBA increased in all of the groups.
\end{abstract}

KEY WORDS: oil seeds, yolk, fatty acids, TBA, storage

\section{INTRODUCTION}

Numerous studies (Aymond and Van Elswyk, 1995; Roth-Maier et al., 1995) have shown that eggs can be enriched in polyunsaturated fatty acids (PUFA) by feeding laying hens diets containing vegetable or fish oils or oil seeds rich in PUFA. Enriching eggs in PUFA is presently viewed by producers as production of nutraceutics (Trziszka, 2000) and by consumers, as specific help in preventing diseases of civilization (Scientific Conference on Dietary Fatty Acids and Cardiovascular Health, 2001). The objective of this study was to determine the effect of dietary composition and length of storage of eggs on changes in the fatty acid (FA) profile of egg yolks.

\footnotetext{
${ }^{1}$ Corresponding author: e-mail: boruta@delta.sggw.waw.pl
} 


\section{MATERIAL AND METHODS}

The study was conducted on eggs from Messa 45 hens divided in week 25 of life into 3 groups of 30 hens each. The hens were fed three diets with similar protein and energy contents (about $11 \mathrm{MJ} \mathrm{ME} / \mathrm{kg}$ and $180 \mathrm{~g}$ crude protein $/ \mathrm{kg}$ ): C - control diet without oil seeds, and two experimental diets, D1 and D2 containing (g/kg diet): rapeseed, 40; linseed, 30; and evening primrose seed, 20. Diet D2 contained vitamin E, $200 \mathrm{mg} / \mathrm{kg}$, as an antioxidant. Fresh eggs and eggs stored for 3 and 6 months at $-25^{\circ} \mathrm{C}$ were analysed. In fat extracted from yolks by the method of Washburn and Nix (1974), the FA content and level of thiobarbituric acid reactive substances (TBA) were determined. The separation and assay of FA were performed on a HP 6890 gas chromatograph, Ultra 2 column, $25 \mathrm{~m}$ long with an internal diameter of $320 \mu \mathrm{m}$. The degree of fat oxidation was assessed using the TBA test, and the results expressed in extinction units on an Epol spectrophotometer at a wavelength of $532 \mu \mathrm{m}$ (Pijanowski, 1984).

The results were subjected to statistical analysis using two-way analysis of variance (SPSS 11.0).

\section{RESULTS AND DISCUSSION}

Analysis of the obtained results showed a significant impact of diet and length of storage of eggs on the share of the fatty acids. It was shown that the MUFA and PUFA content in total assayed FA decreased with storage time as compared with fresh eggs. Regardless of the duration of storage, group D2 eggs had a higher PUFA level as compared with group C. Even after 6 months of storage, the PUFA n-3 and n-6 levels in eggs from chickens fed diet D2 was high. On the basis of these results it can be said that the addition of vitamin $\mathrm{E}$ had a favourable effect on maintaining a high share of PUFA in the yolks of eggs in group D2. The observed changes in the PUFA content shows that as expected, vitamin E slowed down the oxidation of fats in egg yolks. The results pertaining to the FA in the yolks of fresh eggs support the opinion of Sauveur (1994), who showed that vitamin E facilitates the accumulation of PUFA in egg yolks. The results of this study fail, however, to support the conclusion of Trziszka (2000) about the high stability of PUFA in eggs yolks. As the duration of storage increase, TBA extinction increased in all of the groups. Statistical analysis of the obtained results showed a significant effect of both the diet and duration of storage on the degree of fat oxidation. The results of the TBA test differ from those of Płotka and Sroczyński (1984), who stored frozen eggs for 6,9 and 12 months and found high variability in the peroxide and benzidine value and TBA. 


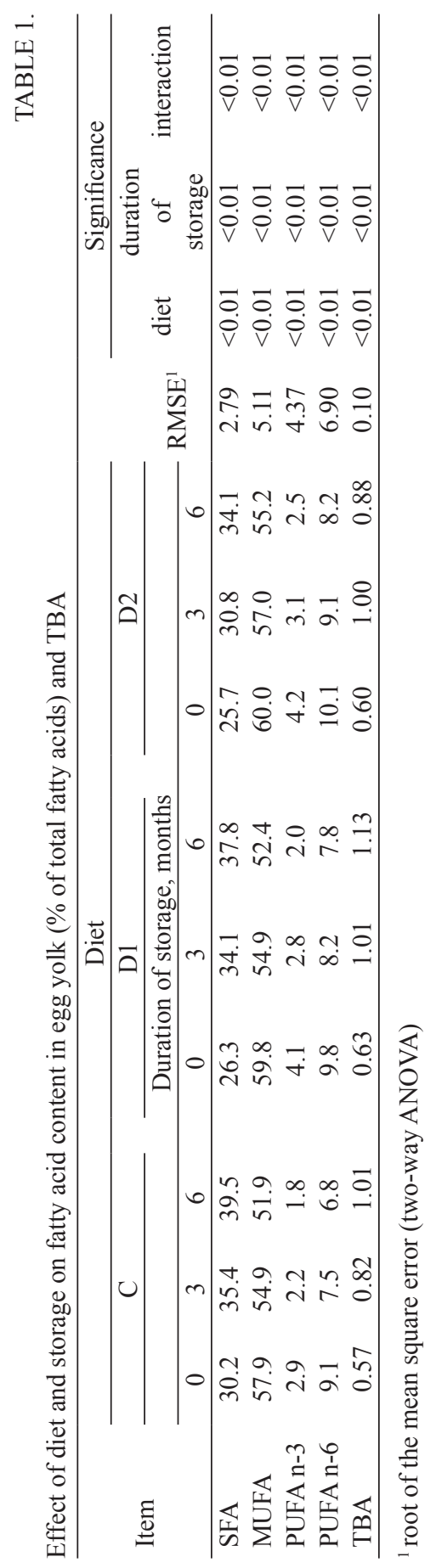


In respect to all of the studied traits, the estimated interaction of the applied diet and period of storage of eggs was found to be significant.

\section{CONCLUSIONS}

Incorporating oil seeds into diets resulted in an increase in the PUFA level in egg yolks. During storage of eggs, the PUFA content in total FA declined. Adding vitamin $\mathrm{E}$ to the feed slowed down the oxidation of fat, protecting the valuable unsaturated fatty acids.

\section{REFERENCES}

Aymond W.M., Van Elswyk M.N., 1995. Yolk thiobarbituric acid reactive substances and n-3 fatty acids in response to whole and ground flaxseed. Poultry Sci. 74, 1388-1394

Pijanowski E., 1984. Epitome of Chemistry and Technology of Dairying (in Polish). Vol. 1. PWRiL, Warszawa, pp. 53-106

Płotka A., Sroczyński E., 1984. Changes in some quality indices of frozen yolks during storage. Zesz. Nauk. Drob. 79-91

Roth-Maier D.A., Kirchgessner M., 1995. Untersuchungen zum Einsatz von 00-Rapssaat in der Geflügelfütterung. Arch. Geflügelk. 59, 241-246

Sauveur B., 1994. Variations initiales de la composition de l'oeuf. In: J.L. Thapon, C.M. Bourgeois (Editors). L'oeuf et les Ovoproduits. Tec Doc, Paris, pp. 70-84

Summary of the Scientific Conference on Dietary Fatty Acids and Cardiovascular Health, 2001. Conference the American Heart Association. Circulation 103, 1034-1039

Trziszka T., 2000. Egg production. Scientific Base, Technology and Practical Application. Agricultural University of Wrocław (Editor)

Washburn K.W., Nix D.F., 1974. A rapid technique for extraction of yolk cholesterol. Poultry Sci. $53,1118-1122$

\section{STRESZCZENIE}

\section{Wpływ składu diety i czasu przechowywania jaj na zmiany profilu kwasów tluszczowych w żóltkach}

Celem podjętych badań było określenie wpływu składu diety i czasu przechowywania jaj pochodzących od kur Messa 45 na skład kwasów tłuszczowych (FA) w żółtkach. Grupy doświadczalne żywiono dietami D1 i D2 zawierającymi nasiona rzepaku, lnu i wiesiołka. W grupie D2 do mieszanki paszowej dodano przeciwutleniacz - witaminę E, $200 \mathrm{mg} / \mathrm{kg}$. Oznaczono zawartość kwasów tłuszczowych i poziom TBA w żółtkach jaj świeżych i przechowywanych przez 3 i 6 miesięcy w temperaturze $-25^{\circ} \mathrm{C}$. Wykazano, że zarówno stosowana dieta jak i długość okresu przechowywania jaj miały istotny wpływ na zawartość MUFA i PUFA w sumie oznaczanych FA. Zmiany zawartości PUFA wskazują, że witamina E spowolniła proces utleniania tłuszczu żółtek jaj. W czasie przechowywania jaj rosła wartość ekstynkcji TBA we wszystkich grupach. 